\title{
Employee Performance Influenced by Their Quality of Work Life and Work Discipline
}

\author{
Lita Wulantika Mentari Zhalzabella Putri \\ Department of Business Management \\ Universitas Komputer Indonesia \\ Bandung, Indonesia \\ lita.wulantika@email.unikom.ac.id
}

\begin{abstract}
This study aims to determine the effect of quality of work life and work discipline on employee performance at Saripetojo Ice Industry Department Agronesia Inc. Bandung. The method used in this research is descriptive - verification method, the sample used in this study is random sampling. The analysis used is multiple linear regression analysis, classical assumption test, Pearson correlation analyses, determination coefficient analysis by hypothesis test using T-Test and F-Test by using the SPSS 17.0 software. The result showed that the most dominant influence on employee performance in Saripetojo Ice Industry Department Agronesia Inc.
\end{abstract}

Keywords - Quality of work life, Work discipline, employee performance

\section{INTRODUCTION}

Every company or organization can run its business well because of the human resources in it. Human resources are the only resource that has desires, skills, knowledge, encouragement, power and work [1]. Failure to manage human resources can lead to disruption in the achievement of organizational goals, both performance, profit, and organizational survival.

A harmonious relationship between leaders and subordinates must also be well maintained. Because if the employee's work environment is not conducive and uninspired, then the work spirit of the employees themselves will decrease, which in turn will result in the difficult achievement of the targets set by a company.

The goals and targets will be easily achieved or realized if each employee complies with all the regulations and policies adopted by the organization and there is high discipline towards compliance. In this case discipline is a factor to achieve a goal. This shows that work discipline is a condition for the realization of organizational goals.
Respect for humans in their work environment is very important. If employees are not satisfied with the awards given by the company, employees will face difficulties in completing their work which will affect work discipline.

Employee performance is one of the dimensions that can be used to measure, evaluate the strength of employees in surviving and carry out their duties and obligations to the organization where they take shelter. Employees are required to be able to carry out tasks that are charged to him well, namely by optimizing work time, discipline, and honesty in order to achieve work with high quality and quantity.

Quality of Work Life as an organizational development technique designed to improve organizational functions by humanizing the workplace, so that it is more democratic and involves employees in decision making.[2] the quality of work life usually strongly supports employee democracy at all levels and encourages their participation in decision making. There are nine indicators in the approach to the quality of work life developed but in this study the author only uses four indicators to limit the problem based on the phenomenon in the company, namely: (1) employee participation, (2) career development, (3) conflict resolution, (4) fair compensation. [3]

Discipline is the attitude of willingness and willingness of a person to obey and comply with the prevailing regulatory norms around him, and good employee discipline will accelerate the achievement of company goals, while a degenerate discipline will be a barrier and slow down the achievement of companygoals.[4]

According to [4] states that indicators of work discipline are: (1) compliance with the provisions of working hours, (2) employee attendance, (3) obedience to basic rules abaout dress and behavior in work, (4) compliance with standard operating procedures (SOP) in carrying out work. 
Performance is the output produced by functions or indicators of a job or profession within a certain time Indicators used to measure employee performance according to [5] including: (1) quality of work, (2) quantity of work, (3) cooperation, (4) responsibility.

Thus, the purpose of this research is to examine the impact of quality of work life and work discipline to employee performance.

\section{METHOD}

The research method used is descriptive verification method. Definition of Descriptive Analysis Methods according to [6] are as follows:

"Descriptive method is research conducted to find out the existence of independent variables, either only on one variable or more (stand-alone variables) without making comparisons and looking for the relationship of the variables with other variables".

Descriptive method is intended to determine the quality of work life and work discipline on employee performance.

While the understanding of the verification method according to [7] in [8] is as follows:

"The verification method to check whether or not it is explained to test a method with or without improvements that have been carried out in another place by overcoming problems similar to life".

The verification method is to find out the quality of work life and work discipline on employee performance. Sources of data used in this study through questionnaires and observations, because researchers collect information from further processed data and data presented by other parties.

The type of data used by researchers in this study is secondary data on the quality of work life and work discipline on employee performance at Saripetojo Ice Industry Department Agronesia Inc. Bandung is secondary data.

This study uses data samples of the quality of work life, work discipline and employee performance at Saripetojo Ice Industry Department Agronesia Inc. Bandung. This study uses a random sampling technique from employees of Saripetojo Ice Industry Department Agronesia Inc. Bandung. A total sample of 53 respondents. The design of the data analysis used is multiple linear regression. While testing the hypothesis using the T-test and F-test with a significance level of $5 \%$. Classical assumption testing used in this study includes tests of normality, multicollinearity, and heteroscedasticity.

\section{RESULTS AND DISCUSSION}

\section{Multiple Linear Regression Analysis}

Multiple regression analysis is used by researchers with the intention to analyze the linear relationship between the independent variable and the dependent variable. In other words, to find out the quality of work life and work discipline on employee performance. By using SPSS 17.0 software, the following test results are obtained:

$$
Y=4.134+0.551(X 1)+0.289(X 2)+20.5 \%(\varepsilon)
$$

$\mathrm{C}=4.134$ Shows if the quality of work life and work discipline are 0 , the growth of employee performance is 4.134

$\beta_{1}=0.551$ Shows the magnitude of the increase in employee performance if the quality of work life increases by one unit, it is predicted that the growth of employee performance will increase by 0.551

$\beta_{2}=0.289$ Indicates the magnitude of the increase in employee performance if work discipline increases by one unit then predicted growth in employee performance will increase by 0.289

$\varepsilon \quad=20.5 \%$ Other variables are not examined.

\section{Classic Assumption Test}

\section{Normality Test}

Requirements for passing the normality test, the probability value must be greater than 0.05 (> 5\%). by using SPSS version 17.0 software, the calculation results obtained Kolmogorov value of 0.985 greater than 0.05 . These results indicate that the residues in the model are normally distributed, so the model has fulfilled one assumption for regression testing.

\section{Multicollinearity Test}

From the results obtained it appears that there is no strong correlation coefficient between the variables of quality of work life with work discipline, so that there is no linear relationship between independent variables. These results indicate that there is no multicolinearity between independent variables in the regression model, so the model meets one of the requirements for regression testing.

\section{Heteroscedasticity Test}

From the graphs obtained, it appears that the point spreads randomly, so it can be concluded that the data is homoscedasticity. These results indicate that the regression model is free from the presence of heteroscedasticity, so that the model meets one of the requirements for regression testing. 


\section{Correlation Analysis}

From the tests that have been done, the following results are obtained:

1. The closeness of the relationship between the quality of work life $\left(\mathrm{X}_{1}\right)$ and employee performance (Y) of 0.876 shows that the relationship between the two variables is very strong (in the interval of 0800 - 1.00). The direction of a positive relationship between the quality of work life and employee performance shows the high quality of work life will affect the increase in employee performance.

2. The closeness of the relationship between work discipline $\left(\mathrm{X}_{2}\right)$ and employee performance $(\mathrm{Y})$ of 0.857 shows that the relationship between the two variables is very strong (in the interval 0.800 1.00). The direction of a positive relationship between work discipline and employee performance indicates the high level of work discipline will affect the increase in employee performance.

3. The closeness of the relationship between the quality of work life $(\mathrm{X} 1)$ and work discipline $\left(\mathrm{X}_{2}\right)$ with employee performance (Y) of 0.892 shows that the relationship between the two variables is very strong (in intervals of $0.800-1.00$ ). The direction of a positive relationship between the quality of work life, work discipline and employee performance shows the high quality of work life and work discipline will affect the increase in employee performance.

\section{Determination Coeffcients Analysis}

From the results obtained, the R-squared value of 0.795 or $79.5 \%$ shows that the influence of the quality of work life and work discipline on employee performance simultaneously is $79.5 \%$, while the remaining $20.5 \%$ is influenced by other variables.

\section{Hypothesis Tesiting}

\section{Partial Hypothesis Test (T Test)}

- Quality of work life on employee performance Partial test results influence the quality of work life on employee performance obtained the value of $t_{\text {count }}=$ $3,848>2,009$ ( $\left.t_{\text {table }}\right)$. Therefore, it can be concluded that partially the quality of work life influences employee performance.

\section{- Work discipline on employee performance}

Partial test results of the influence of work discipline on employee performance obtained $t_{\text {count }}=$ $2.615>2009\left(t_{\text {table }}\right)$. Therefore, it can be concluded that partially work discipline influences employee performance.

\section{Simultaneous Hypothesis Test (Test F)}

Quality of work life and work discipline towards employee performance Simultaneous testing results of the influence of the quality of work life and work discipline on employee performance obtained values $\mathrm{f}_{\text {count }}$ $=97.018>3.18$ ( $\left.f_{\text {table }}\right)$. Therefore, it can be concluded that simultaneously, the influence of the quality of work life and work discipline affect employee performance.

The quality of work life in which is measured through 4 indicators, namely employee participation, career development, conflict resolution, and fair compensation, including the poor criteria with the lowest score of career development. But in general, all indicators are in poor criteria.

Work discipline which is measured through 4 indicators, namely compliance with the provisions of working hours, employee attendance, adherence to basic rules on dress and behavior in work and adherence to standard operating procedures in carrying out work. Included in the unfavorable criteria with the lowest score, namely employee attendance. In general, all sizes fall into poor criteria.

Employee performance in which is measured through 4 indicators, namely quality, quantity, cooperation and responsibility are included in the criteria of not good with the lowest score, namely employee attendance. In general, the size for employee performance falls into poor criteria.

Partially this study shows the influence of the quality of work life on employee performance, this is indicated by testing the hypothesis which states that there is a significant influence on the quality of work life on employee performance at Saripetojo Ice Industry Department Agronesia Inc. Bandung.

Partially this study shows the influence of work discipline on employee performance, this is indicated by testing the hypothesis which states that there is a significant influence of work discipline on employee performance at Saripetojo Ice Industry Department Agronesia Inc. Bandung.

Simultaneously, this study shows the influence of the quality of work life and work discipline on employee performance, this is indicated by testing the hypothesis which states that there is a significant influence on the quality of work life and work discipline on employee performance at Saripetojo Ice Industry Department Agronesia Inc. Bandung.

Based on the conclusions above, the author would like to submit the following suggestions: 
This study was conducted to observe the effect of quality of work life and work discipline on employee performance. Based on verification analysis, it showed that quality of work has positive and significant effect on employee performance. The result means that the more increasing levels of quality of work life is, the better performance of employees will be. This research is in accordance with the results of [9]. The estimation results are shown in the value of the influence of the quality of work life on performance partially there is a close relationship between the quality of work life on performance. In addition, it is also in accordance with the results of research from [10], [11].

Then obtained a significant influence between Work Discipline on Employee Performance in PT Agronesia Department of Saripetojo Ice Industry Bandung. This research is in accordance with the results of [12]. Hypothesis test results show that work discipline has a significant effect on the employee performance of PDAM Tirta Mangutama Badung Regency. In addition, it is also in accordance with the results of research from [13], [14].

\section{REFERENCES}

[1] Sutrisno,Edi, MSDM, Jakarta:Kencana Pernanda Media Group, 2009

[2] Greenberg,Jerald \& Baron. Behavior in Organizations (Understanding and managing the human side of work), eight edition, Prentice Hall, 2003.

[3] Cascio, Wayne F,Managing Human Resources:Productivity, Quality of Work life, Profit, seventh edition.New York:McGraw-Hill Irwin,2006.

[4] Sutrisno,Edi, MSDM, Jakarta:Kencana Pernanda Media Group, 2011.

[5] Wirawan.,Evaluasi Kinerja Sumber Daya Manusia. Jakarta: Salemba Empat,2009.

[6] Sugiyono. 2011. Metode Penelitian Pendidikan (Pendekatan Kuantitatif, Kualitatif dan R\&D).Bandung: Alfabeta

[7] Mashuri \& Zainuddin,Metodologi Penelitian, Bandung, PT. Refika Aditama,2008.

[8] Umi Narimawati.,Riset Manajemen Sumber Daya Manusia. Jakarta: Agung Media,2007.

[9] Afrizal, Nasir Aziz, Mukhlis Yunus. 2012. "Pengaruh Kualitas Kehidupan Kerja (Quality Of Work Life), dan Kompensasi Terhadap Loyalitas Serta Dampaknya pada Kinerja Karyawan PT. Bank Aceh Cabang Bener Meriah". Jurnal Ilmu Manajemen Pascasarjana Universitas Syiah Kuala. ISSN 2302-0199. PP: 1-18

[10] Muindi, Florence, Lecturer Professor Peter K'Obonyo, Professo. 2015. "Quality Of Work Life, Personality, Job Satisfaction, Competence, And Job Performance: A Critical Review Of Literature". European Scientific Journal. E - ISSN 1857- 743

\section{CONCLUSION}

This study was conducted to observe the effect of quality of work life and Work discipline on employee performance.Based on the descriptive analysis, it showed that the quality of work life which is owned by employee Saripetojo Ice Industry Department Agronesia Inc. Bandung is still not doing well., as well as employee Work disciplinet is included in still not doing well category.Based on verificative analysis, it showed that quality of work life has positive and significant effect on employee performance. The result means that the more increasing levels of quality of work life is, the better performance of employees will be. thus there is also the influence of work discipline on employee performance. Simultaneously there is an influence on the quality of work life and work discipline on employee performance

\section{ACKNOWLEDGEMENTS}

The authors would like to thank the UNIKOM Rector, Dr. Ir. H. Eddy Soeryanto Soegoto., and Dean of the Faculty of Economics and Business Prof. Dr. Hj. Dwi Kartini Yahya., SE., Spec. Lic, who have given the opportunity to do this research.
[11] Dwi Wahyu Artiningsih, Syahdi Rasyid. 2013. "Pengaruh Locus Of Control, Organization Citizenship Behavior dan Kualitas Kehidupan Kerja terhadap Kinerja Karyawan (Studi Kasus di Rumah Sakit Umum Daerah Kotabaru)". Jurnal aplikasi manajemen, Vo1. 11, No. 3, ISSN: 1693-5241

[12] Frisca Tuju. 2015. Pengaruh Lingkungan Kerja, Stres Kerja dan Disiplin Kerja Terhadap Prestasi Kerja Pegawai BPBD Provinsi Sulawesi Utara. Jurnal EMBA Vol.3 No.2 Juni 2015, Hal. 629-638. ISSN 2303-1174.

[13] Apalia Ekakoron Anthony. 2017. Effects of Discipline Management on Employee Performance in an Organization: The Case of County Education Office Human Resource Department, Turkana County. International Academic Journal of Human Resource and Business Administration, vol. 2, issue 3, pp. 1-18. ISSN 2518.2374.

[14] Endarwita dan Rini Herlina. 2016. "Pengaruh Kompensasi dan Disiplin kerja Terhadap Kinerja Karyawan (studi kasus pada PT. FIF Group di Kabupaten Pasaman)". E-Jurnal Apresiasi Ekonomi Volume 4, Nomor 2. PP: 117 - 125 ISSN : 2337 - 3997 